\title{
Infrastructure as a way to measure the maturity of knowledge management in product development
}

\section{Caio W. Nomiyama*, Robert Eduardo Cooper Ordoñez}

\section{Abstract}

This research supports a master's degree thesis, seeking the associations between product development, knowledge management bases (People, Communication and Infrastructure) and maturity models for the definition of indicators of maturity level of knowledge management in product development. This part of the research focused on the study of the Basis 'Infrastructure'. The final objective of this research is to define indicators that will measure the level of maturity in the knowledge management of the products development of the organizations.

\section{Key words:}

Infrastructure, Knowledge management, Product development

\section{Introduction}

There are several studies that affirm that knowledge management is currently the main capacity responsible for gaining competitive advantage of organizations. Proof of this is the importance of knowledge in the modern economic landscape where, according to the World Bank, $64 \%$ of the world's wealth comes from knowledge.

The objective of this work is to identify the associations between product development (PD), knowledge management $(\mathrm{KM})$ bases $^{1}$ and maturity models for the definition of indicators that will measure the level of maturity in the knowledge management of the products development of the organizations.

This work supports a master's degree thesis and this part of the research focused on the study of the Basis 'Infrastructure'.

\section{Results and Discussion}

Chart 1 shows the Knowledge Management Maturity Model (KMMM) surveyed and the link with the proposed bases $^{1}$ (People, Communication and Infrastructure) and Chart 2 shows the relation between the dimensions of $P D$ and the Bases of KM:

Chart 1. Different KMMM's and the bases that are related in their models.

\begin{tabular}{|c|c|c|c|}
\hline \multirow{2}{*}{ Models } & \multicolumn{3}{|c|}{ Bases $^{1}$} \\
\cline { 2 - 4 } & People & $\begin{array}{c}\text { Communi- } \\
\text { cation }\end{array}$ & $\begin{array}{c}\text { Infra- } \\
\text { structure }\end{array}$ \\
\hline Knowledge Journey & $\mathrm{X}$ & & $\mathrm{X}$ \\
\hline KMMM (Infosys) & $\mathrm{X}$ & & $\mathrm{X}$ \\
\hline KMMM (Software Industry) & & $\mathrm{X}$ & $\mathrm{X}$ \\
\hline Knowledge Process Quality Model (KPQM) & & & $\mathrm{X}$ \\
\hline 5iKM3 & $\mathrm{X}$ & & $\mathrm{X}$ \\
\hline KMMM (Technology) & & & $\mathrm{X}$ \\
\hline KMMM (Siemens) & $\mathrm{X}$ & $\mathrm{X}$ & $\mathrm{X}$ \\
\hline $\begin{array}{c}\text { General Knowledge Management Maturity } \\
\text { Model (G-KMMM) }\end{array}$ & $\mathrm{X}$ & & $\mathrm{X}$ \\
\hline KMMM (Nuclear Industry) & $\mathrm{X}$ & $\mathrm{X}$ & $\mathrm{X}$ \\
\hline
\end{tabular}

Chart 2. Relation between PD and Bases of KM.

\begin{tabular}{|c|c|}
\hline Dimensions of PD & Bases of KM \\
\hline Strategy & $\begin{array}{c}\text { People; } \\
\text { Communication }\end{array}$ \\
\hline Organization & Organizational culture \\
\hline Activities / information & People \\
\hline Resources & Infrastructure \\
\hline
\end{tabular}

In the Resources dimension an important tool is the Product Data Management (PDM), it was observed that this tool involves all the bases of $\mathrm{KM}$ and can be used as an important means to evaluate the $\mathrm{KM}$ in the $\mathrm{PD}$, as shown in Image 2.

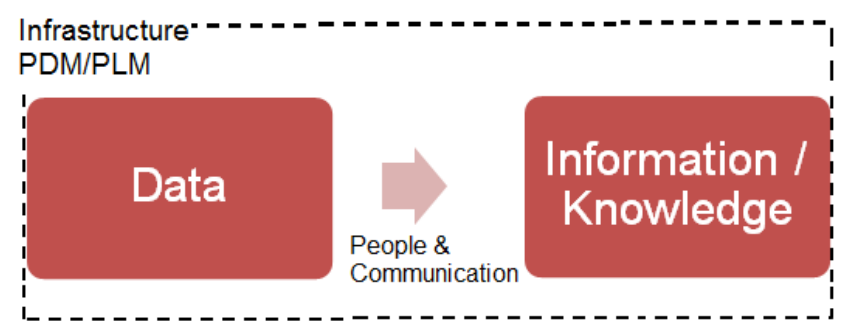

Image 2. PDM/PLM and the bases of KM

Thus, it was proposed indicators related to infrastructure, as shown in Chart 3.

Chart 3. Proposed indicators

\begin{tabular}{|l|l|}
\hline \multicolumn{1}{|c|}{ Function } & \multicolumn{1}{c|}{ Indicator } \\
\hline $\begin{array}{l}\text { Organization and storage of } \\
\text { data and information }\end{array}$ & $\begin{array}{l}\text { Existence of an effective data and } \\
\text { information management } \\
\text { infrastructure }\end{array}$ \\
\hline Distribution of knowledge & $\begin{array}{l}\text { Existence of an effective } \\
\text { infrastructure for information and } \\
\text { communication technology (ICT). }\end{array}$ \\
\hline Utilization & $\begin{array}{l}\text { Degree of use of existing } \\
\text { infrastructure }\end{array}$ \\
\hline
\end{tabular}

\section{Conclusions}

It was possible to define linkages between the proposed $\mathrm{KM}$ bases, maturity models for $\mathrm{KM}$ and product development process, validating the relationship and, thus, it is possible to define indicators related infrastructure for measuring the maturity of KM in PD.

\footnotetext{
${ }^{1}$ De Marco, V.; Cooper, R. E. Pilares para a gestão do conhecimento. XXIII Simpósio de Engenharia de Produção. Bauru, SP, 2016.
} 